\title{
THE END OF REPRESENTATIVE POLITICS BY SIMON TORMEY (2015, CAMBRIDGE, JOHN WILEY \& SONS, POLITY PRESS)
}

LAURA BoldVAI-PETHES ${ }^{l}$

Representative politics is in crisis. Trust in politicians is at an all-time low. These are the initial remarks in Simon Tormey's new book. Simon Tormey is Professor of Political Theory at the University of Sydney. His research areas are Contemporary Political Theory and Global Politics, Critical Theories and Global Civil Society. In his new book his main research questions are the following: Why do people reject representative politics? Where does that rejection come from? What comes after representative politics?

Representative politics is a democratic system of political authority through which a group of people represent citizens. In this system there is basic political equality, freedom of speech and expression. From Hobbes to contemporary authors like Habermas, Fishkin, Keane, Manin, Vieira, or Dunn, the inevitability and viability of representative democracy has been in the forefront of interest. But whereas Thomas Hobbes argued for the utility of representative politics over other modes of legitimating authority, in particular the divine right of kings, current scholars mostly argue for the "death of democracy". The discourse of representation preceded the spread of democratic institutions and practises. Moreover, such authors claim that democracy is not obviously equal to representation-based politics. What is new in Tormey's book in comparison to the existing literature is that he seeks to offer new ideas about how democracy should be reconfigured in order to keep it alive.

What are the relevant factors that indicate that there has been a decline in citizens' engagement with representative politics? There are four different indicators that could explain this freefall. The number of active voters is a direct measure of engagement, and it is declining. The less people feel their vote counts, the less liable they are to vote. Another big problem, according to the author's research, is that political parties are failing to make a connection with the public,

1 Laura Boldvai-Pethes is a Ph.D. student at Corvinus University of Budapest, e-mail: pethes.laura@ gmail.com 
so elections are becoming "presidential". In the meantime, grassroots politics are proving very successful because they keep in touch with the public. The third component of the crisis is the decreasing level of trust in politicians who are the least trusted group in society because of their broken promises, corruption, etc. Politicians are reduced to agents of governance if people do not feel that they are being represented by them. A decrease in knowledge and interest in politics is also a very important sign of a crisis in representative politics.

At the beginning people created nations in order that they should represent them. These first nations were absolutist; absolute power guaranteed peace. The peculiarities of the system were the following: new classes emerged, the roots of freedom were watered and they provided more opportunities for the spread of ideas and messages. After the English Civil War resistance towards the absolutist state arose, to which representative politics was the solution. Not everybody was pleased with the idea of representation; many people were worried about what would happen if the wrong people were elected. Nevertheless, representative parties were successful because they offered an opportunity for individuals to be represented on the basis of several axes - principally identities, ideologies and interests. But these parties were privileged places for intellectuals, and involved the rotation of elites. Nowadays, representative politics only works if people recognize themselves as members of a larger aggregate.

After examining the contours of crisis in representative politics in general, Tormey presents his own view. One of the biggest problems is the decadence, or the failure of the political class. Whereas these individuals used to be aristocratic figures, nowadays they are largely associated with scandals (sex, corruption) which destroy trust. Another consideration is the changing behaviour of citizens. Success in a democratic society means that all kinds of welfare is taken for granted; accordingly, people became complacent, apathetic, and unmoved by politics. Moreover, citizens mostly focus on their private lives instead of on matters of public concern. This is a big problem for politics, because politics by nature requires that we think about common, collective interests. The third explanation for the rejection of politics is the transformation of the role and image of the state. The state used to maintain the welfare system, whereas in the neoliberal era the public sector is depoliticized. There is another cause for the rejection of representative politics too; namely, the effect of the 'long revolution' which includes the influences of modernity, globalization, and individualization. The key elements of change are the following: Employment has become more flexible so there has been an increase in the flow of people, culture and ideas, and these opportunities for structural mobility have undermined individuals' sense of identity. Stable social structures, identities and interests are continuously under pressure. And, because of individualization, scepticism about the special 
qualities of politicians has increased. The book Bowling alone by Robert Putnam describes the situation well.

Parties were formed to represent the needs and interests of various kinds of identities and interests. But nowadays, parties are too complex and ideologies have been divided. People are no longer interested in implementing a distinctive vision. Parties are also outmoded with their hierarchical structures. Politicians are accepted only if they become individualized. According to Tormey, parties should change their structural hierarchical forms to a more coalition- networkand affinity group-based way of operating. New parties should use the advantages of social media and organise groups with the help of the internet. Citizens do not need representatives anymore; they can combine with each other and have their "own voice". New parties will come and go; they may be founded for single issues (e.g.: to humiliate the political class). Accordingly, they are no longer substantial organizations, but vehicles of convenience. New parties will be totally different from existing political parties because they will not represent others; consequently, they do not require as much responsibility and accountability.

After providing the empirical background, the author provides an interesting case study of the Spanish Indignados movement which took place in Spain in 2011 involving a conflict between the political elites and grassroots movements. The case effectively illustrates how the previously described trends and tendencies are changing the politics of liberal democracy. Based on real data Tormey shows how the individualization of politics is patterning affinity, identification and mobilization. According to the case study, the new parties' primary purpose is to achieve one specific goal; it has limited ambitions and makes a limited set of claims; it is also anti-representative; parties are just tools for achieving single goals. As an example, one of the new parties (Partido X: Partido del Futuro) was only founded to create a social and political base for a second, more democratic transition. To confirm how these new parties are quickly growing and shrinking, here are the numbers: 490 new parties have emerged in Spain since 2010, some of which still resonate, while others generate only a passing flicker of recognition.

What kind of democracy will take place after the death of representation? The author's own suggestion is that we will see (or we have already seen) the decline of representative politics, but not politics as a whole. The key sentences about the changes are the following: power is becoming more diffuse, complex and multiscale. So-called "organized" politics, which refers to competition for power between mass parties, will be replaced by a more evanescent "dis-organized" politics. There will be a transformation from a complex party-based democracy to a new form of democracy in which there are different kinds of parties such as "executive teams", pop-up, micro-, protest or anti-party parties. There will be a rapid increase in the amount of non-party activism, as well as resurgent or 
insurgent political initiatives supported by ICT.

I highly recommend this book to anybody who is interested in this topic, with some limitations. Sometimes the writer repeats himself, and not only in order to emphasize his arguments. Another problem with the book is that the author promised to offer a solution to the crisis of representative politics in vain; in the end, the reader is left wanting. Maybe in the future there will be "dis-organized" democracy, but the author is unable to tell us how it will work.

How will a democracy with more than (or at least) 20 parties work and make decisions? If in the future micro-parties will be founded for single causes, who will take care of the other tasks of the modern state? Who will determine budgets? What about long-term decisions, such as big investments? There is no doubt a point when the days of representative politics will be over because people no longer trust such systems, partly because the current crop of politicians don't keep their promises, but so far it is not clear how "dis-organized" democracy will replace it.

Could policy expert teams be an answer to such problems? They should be individual politicians (as the author suggests in his book) who work together in teams not only for one cause or goal, but for the purpose of long-term decisionmaking (e.g.: on matters pertaining to the budget, education or health system). The author states in his book that the allocation of such tasks will be one solution for creating a well-functioning democracy. In the future, instead of parties a modern parliament may work through using the support of governmental expert teams for all issues. This system could support Tormey's ideas about elections: as he writes, elections should become more personalized because people prefer to vote for real people instead of lists.

Another issue is the end of state monopoly. But then who will wield power? One solution is that most financial and monetary decisions will depend on multinational organizations. But if this occurs, then people will also lose their freedom. Because instead of the state, multinational companies will influence people's lives. Moreover, because people's lives are centred around consumption, they will be even more tightly controlled by multinational organizations than they used to be by governments. Consequently, it is not evident that after the end of representative politics grassroots politics will gain power, because nongovernmental organizations could play as big (or maybe a bigger?) part in decision making than non-party based politicians.

In sum, Tormey writes about a future in which representative elites vanish and are replaced with a new form of democracy with horizontal parties which can establish a better and more ethical political future. 